\author{
I.A. Farbun, V.A. Trykhlib
}

\title{
Porous Structure Influence of Coconut Carbon Sorbents and Acidity on the Sorption of Some Biologically Active Organic Compounds
}

\author{
Institute for Sorption and Problems of Endoecology, Kyiv, Ukraine, mandarin3169@gmail.com
}

\begin{abstract}
The paper investigates the regulation of the hydrophobicity of KARBONTM carbon adsorbents by restoring its surface during heat treatment in argon and hydrogen, as well as oxidizing it with nitric acid. The sorption capacity of KARBONTM with respect to the tryptophan, arginine, indole, creatinine and vitamin $\mathrm{B}_{12}$ as biologically active organic compounds of different molecular weight was studied. It was determined that the adsorption capacity of KARBONTM samples with respect to all the studied substances changes as follows: Ind $>\mathrm{Cr}>\mathrm{Trp}>\mathrm{Arg}>\mathrm{B}_{12}$. It has been shown that the sorption capacity of argon-treated KARBONTM adsorbent at $\mathrm{pH}=7.5$ is $2.6 ; 2.7$ and $0.09 \mathrm{mmol} / \mathrm{g}$ in relation to tryptophan, creatinine and vitamin $\mathrm{B}_{12}$, respectively. The adsorption capacity of these compounds is almost unchanged when the acidity changes from 7.5 to 2.0. The results obtained allows the use of KARBONTM adsorbent as a therapeutic and/or prophylactic agent for oral administration in chronic kidney and liver diseases, as well as a hemosorbent for the purification of blood outside the body.
\end{abstract}

Keywords: uremic toxins adsorption, amino acids adsorption, carbon adsorbents, tryptophan, arginine, indole, creatinine, vitamine $\mathrm{B}_{12}$.

Received 19 August 2020; Accepted 15 December 2020.

\section{Introduction}

Uremic retention solutes or uremic toxins are products of amino acid-protein metabolism in the human body that accumulates in the blood of patients with the progression of chronic kidney disease (CKD). These uremic toxins lead to disorders of biochemical, physiological and cellular functions, the most severe of which are encephalopathy (uremia and confusion of consciousness) [1].

In the formation of uremic toxins excess of aromatic amino acids, namely, tryptophan, has pronounced dangerous pathogenic effect. Tryptophan causes a number of toxic symptoms and further reduces renal function, i.e. contributes to the progression of CKD [2]. Uremic toxins are grouped into three classes based on their molecular weight and chemical properties: (i) small, water-soluble solutes that are not protein-bound ( $<500 \mathrm{Da})$, which can be easily removed by dialysis; (ii) middle molecules $(500-35000 \mathrm{Da})$, which can be cleared using dialysis membranes with larger pore size or hemodiafiltration; and (iii) proteins as well as hydrophobic, protein-bound uremic toxins $(\approx 500 \mathrm{Da})$ [1].

Medical carbon sorbents are most used for internal environment control of a human body for toxic substances molecules excretion. They have high surface area, great strength, selectivity and high adsorption capacity to various toxins not only from aqueous solutions, but also under physiological conditions in the presence of salt ions, amino acids, peptides and proteins [3]. Some uremic toxins (for example, indoxyl sulfate) exist not only in human body fluids, but also in the digestive tract [4]. Therefore, activated carbon can be used as enterosorbents to remove poisonous, ballast and potentially dangerous substances from the human body by absorbing or neutralizing them in the gastrointestinal tract, thereby reducing the load of toxins on the kidneys [5]. However, activated carbon is very hydrophobic and it is not suitable for the substances adsorption that cause uremia (ionic organic compounds arginine and creatinine) [6].

It is known that in the synthesis of adsorption materials sorbents are preferred, which contain pores of 
different sizes in their structure. This allows the removal of various toxins (low- and medium molecular weight substances, protein compounds). Therefore, in Institute for Sorption and Problems of Endoecology, National Academy of Sciences of Ukraine synthesized activated carbon KARBONTM, which is based on coconut shell [7], is used as a hemosorbent for purification of blood outside the human body [8] due to its high structural and adsorption-kinetic properties [9]. Taking into account the special biochemical and toxicological effects of tryptophan and phenylalanine metabolites on the human body, it was proposed to use $\mathrm{KARBON}^{\mathrm{TM}}$ as an enterosorbent to remove excess aromatic and heterocyclic amino acids [10].

The aim of the present work was to carry out restoration and/or oxidation of the KARBONTM adsorbent surface (to regulate its hydrophobicity), and determine the effect of KARBON ${ }^{\mathrm{TM}}$ surface chemistry on its sorption capacity with respect to tryptophan, arginine, indole, creatinine and vitamine $\mathrm{B}_{12}$ as biologically active substances. We believe that the compliance of the porous structure parameters of the modified carbon materials to the sizes of the molecules removed will be a decisive factor in the efficient implementation of sorption processes.

\section{Materials and methods of research}

The KARBONTM carbon adsorbents (bulk density of $0.35 \mathrm{~g} / \mathrm{cm} 3$, fraction of $0.25-0.63 \mathrm{~mm}$ (enterofraction)), synthesized with the use of additional steam-air activation of commercial activated AquaCarb $607 \mathrm{C}$ carbon (Chemviron Carbon, Belgium) obtained from a coconut shell [7]. The samples of KARBONTM-0.35 adsorbent were reduced with argon and hydrogen at temperatures of $500{ }^{\circ} \mathrm{C}$ ( 1 hour) and $700{ }^{\circ} \mathrm{C}$ (1.5 hours), respectively, and oxidized by boiling in $35 \%$ nitric acid for 1 - 6 hours (OC, static exchange capacity (SEC) is from 0.4 to $2.8 \mathrm{mg}-\mathrm{eq} / \mathrm{g}$ ) and then used to the sorption study of biologically active substances. Substances of analytical grade (Macrochem, Ukraine): L-tryptophan, L-arginine, indole, creatinine and vitamine $\mathrm{B}_{12}$ (purity of $98 \%$, Alfa Aesar, USA) were used as adsorbates.

The porous structure of the carbon materials was studied by low-temperature $(77 \mathrm{~K}$ ) adsorption of nitrogen on a NOVA 2200 surface gas analyzer (Quantachrome, USA). The specific surface area (Ssp.tot, $\mathrm{m}^{2} / \mathrm{g}$ ), the pores volume $\left(\mathrm{V}, \mathrm{cm}^{3} / \mathrm{g}\right)$, the pores radius $(\mathrm{r}, \mathrm{nm})$, and the size distribution of the pore volumes $(\mathrm{dV} / \mathrm{d} \log \mathrm{r}$ ) were calculated by the BET, BJH and density functional theory (DFT) methods with data from the desorption isotherms using AsiQ 3.0 software.

The geometric descriptors (milogP; TPSA, $\mathrm{nm}^{2}$; n$\mathrm{ON}, \mathrm{nm}^{2} ; \mathrm{n}-\mathrm{OHNH}, \mathrm{nm}^{2} ; \mathrm{V}, \mathrm{nm}^{3}$ ) of amino acids, their metabolites, and vitamine $\mathrm{B}_{12}$ were calculated using Molinspiration Cheminformatics method [11] of the Molinspiration website (www.molinspiration.com). The radii of adsorbates molecules $(\mathrm{R}, \mathrm{nm})$ corresponding to the volume of the investigated molecules were obtained with the data in Table 2 .

The absorbing capacity of the carbon materials was studied by adsorption of the substances from physiological solutions, initial concentrations of up to 20 (tryptophan, indole), 24 (arginine), 35.5 (creatinine) and 0.37 (vitamine $\mathrm{B}_{12}$ ) $\mathrm{mmol} / \mathrm{L}$. The sorption experiments were carried out under static conditions with agitation for $4 \mathrm{~h}$ with a $0.1 \mathrm{~g}$ sample of the sorbent that had been dried at $378-383 \mathrm{~K}$ and with $25 \mathrm{~mL}$ of the adsorbates solutions at $\mathrm{pH}=1.5-2.5$ (upper zone - the bottom and body of the human stomach) and 7.0 - 7.5 (lower zone the antrum of the stomach). The $\mathrm{pH}$ was adjusted by adding $0.1 \mathrm{M} \mathrm{HCl}$ solution; the equilibrium value of the acidity was measured on the И-160M pH-meter (Ukraine). The UV absorbance spectra of compounds were recorded using a Shimadzu UV-2450 spectrophotometer (Japan) from 190 to $1000 \mathrm{~nm}$. The equilibrium concentrations of tryptophan, arginine, indole, and creatinine were determined in quartz cuvettes $(l=10 \mathrm{~mm})$ at $\lambda=279,202,269$, and $233 \mathrm{~nm}$, respectively. The content of vitamin $\mathrm{B}_{12}$ was determined by the photocolorimetric method on a KFK-301 colorimeter (Ukraine) at $540 \mathrm{~nm}$.

The sorption capacity $(A, \mathrm{mmol} / \mathrm{g})$ was calculated according to the equation

$$
A=\frac{\left(C_{i n}-C_{e q}\right) V}{1000 m},
$$

where $\mathrm{C}_{\mathrm{in}}$ and $\mathrm{C}_{\mathrm{eq}}$ are concentrations of the adsorbate in the initial and equilibrium solutions, $\mathrm{mmol} / \mathrm{L} ; \mathrm{V}$ is the volume of the solution, $\mathrm{mL} ; m$ is the mass of the sorbent, g.

\section{Results and discussion}

Investigations of the porous structure of the carbon materials show that the adsorption/desorption isotherms of nitrogen with initial KARBON ${ }^{\mathrm{TM}}$ carbon adsorbent as well as treated with argon (hydrogen) or nitric acid KARBONTM belong to type 1 of the IUPAC classification with hysteresis loop type H4 [12] (Fig. 1). The sharp increase of the amount of absorbed nitrogen at a low relative pressure and the presence of a hysteresis loop at moderate and high pressure confirm that these adsorbents are a micro-mesoporous materials.

Micropores and mesopores distribution of

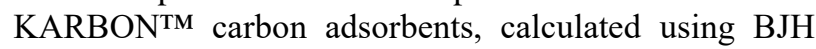

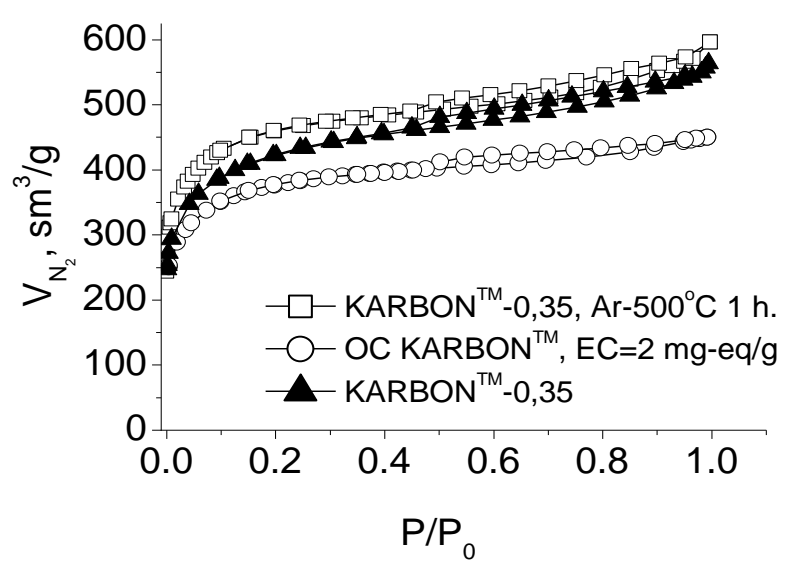

Fig. 1. Adsorption/desorption isotherms of nitrogen on samples of KARBONTM carbon adsorbents. 
and DFT methods, are presented in Fig. 2. Porous structure parameters of the corresponding samples are shown in Table 1. It is seen that the use of different poreforming agents leads to different of pore volumes distribution (Fig. 2 and table 1). Thus, treatment of KARBONTM carbon with nitric acid helps to reduce the amount of mesopores. All adsorbents studied contains micropores with sizes of $0.6-1.0 \mathrm{~nm}$ and mesopores with sizes of $1-1.5$ and $2-3 \mathrm{~nm}$. However, the highest specific surface area and the largest of mesopores volume have the argon-treated of KARBON ${ }^{\mathrm{TM}}$ sample.

a

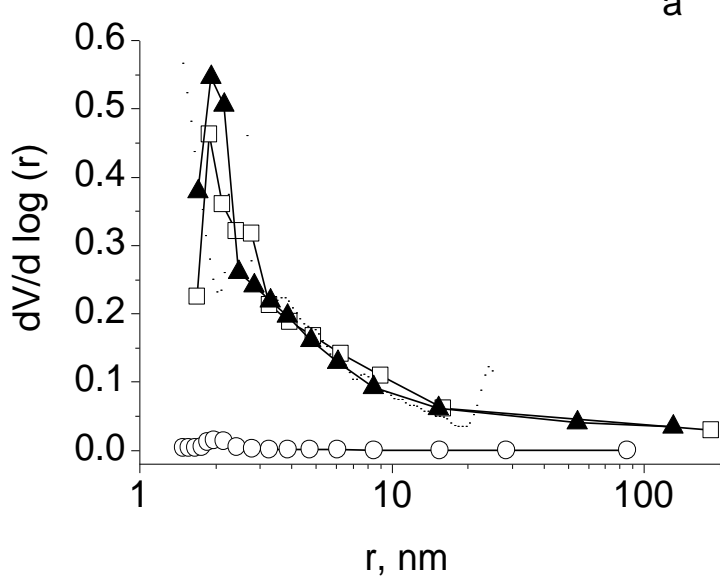

The choice of subjects for the investigation was based on the fact that the amino acids tryptophan and arginine, as well as their metabolites indole and creatinine are representatives of low molecular weight compounds. Indole is a precursor of the hazardous uremic toxin indoxyl sulfate, which is bound to the proteins and is not removed during dialysis; creatinine is an indicator of kidney function and a low-molecular water-soluble toxin that are removed by dialysis (Scheme 1) [1]. Vitamine $B_{12}$ is a model of middle molecular weight toxins which can't be properly removed during

Fig. 2. Differential size distribution curves of the pores (BJH (a) and DFT (b) methods) on samples of KARBONTM carbon adsorbents.

Table 1

Porous structure parameters of KARBONTM carbon sorbents

\begin{tabular}{|l|c|c|c|c|c|}
\hline \multicolumn{1}{|c|}{ Carbon } & $\begin{array}{c}\mathrm{S}_{\text {sp.tot (BET), }} \\
\mathrm{m}^{2} / \mathrm{g}\end{array}$ & $\begin{array}{c}\mathrm{V}_{\text {tot. (BET) }}, \\
\mathrm{sm}^{3} / \mathrm{g}\end{array}$ & $\begin{array}{c}\mathrm{V}_{\text {meso (BJH) }}, \\
\mathrm{sm} / \mathrm{g}\end{array}$ & $\begin{array}{c}\text { Mesopores, } \\
\%\end{array}$ & $\begin{array}{c}\mathrm{R}_{\text {aver. (BET), }} \\
\mathrm{nm}\end{array}$ \\
\hline KARBON $^{\mathrm{TM}}-0,35, \mathrm{Ar}-500^{\circ} \mathrm{C} 1 \mathrm{~h}$. & 1730 & 0.92 & 0.24 & 26.1 & 1.1 \\
\hline KARBON $^{\mathrm{TM}}-0,35, \mathrm{H}_{2}-700^{\circ} \mathrm{C} 1,5 \mathrm{~h}$. & 1596 & 0.91 & 0.25 & 27.5 & 1.1 \\
\hline KARBON $^{\mathrm{TM}}-0,35$ & 1545 & 0.87 & 0.24 & 27.6 & 1.1 \\
\hline OC KARBON $^{\mathrm{TM}}, \mathrm{EC}=0,4 \mathrm{mg}-\mathrm{eq} / \mathrm{g}$ & 1516 & 0.76 & 0.16 & 21.1 & 1.0 \\
\hline OC KARBON $^{\mathrm{TM}}, \mathrm{EC}=1,1 \mathrm{mg}-\mathrm{eq} / \mathrm{g}$ & 1449 & 0.71 & 0.14 & 19.7 & 1.0 \\
\hline OC KARBON $^{\mathrm{TM}}, \mathrm{EC}=2,0 \mathrm{mg}-\mathrm{eq} / \mathrm{g}$ & 1413 & 0.70 & 0.14 & 20.0 & 1.0 \\
\hline OC KARBON $^{\mathrm{TM}}, \mathrm{EC}=2,8 \mathrm{mg}-\mathrm{eq} / \mathrm{g}$ & 1273 & 0.68 & 0.16 & 23.5 & 1.1 \\
\hline
\end{tabular}

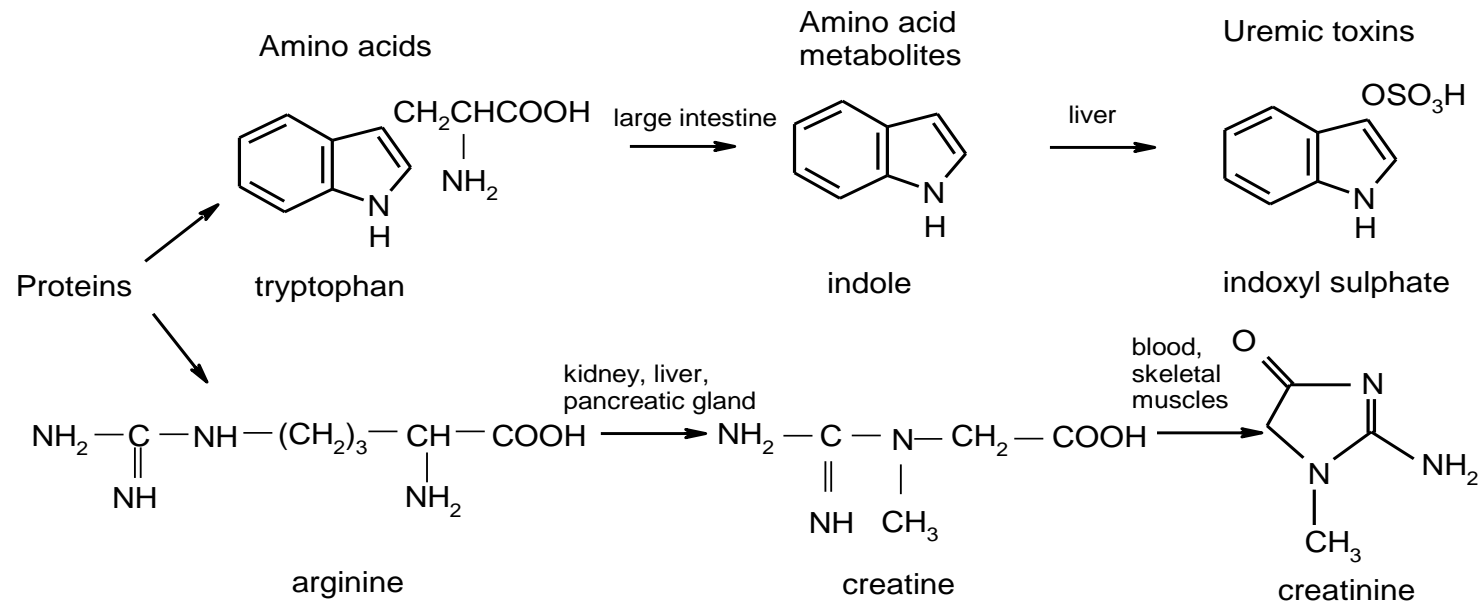

Scheme 1. Amino acids metabolism. 
Table 2

Physico-chemical characteristics of the employed adsorbates

\begin{tabular}{|c|c|c|c|c|c|c|c|}
\hline \multirow[b]{2}{*}{ Adsorbate } & \multirow[b]{2}{*}{ M.w. } & \multicolumn{5}{|c|}{ Molinspiration Cheminformatics method } & \multirow[b]{2}{*}{$\mathrm{R}, \mathrm{nm}$} \\
\hline & & milogP & $\begin{array}{c}\text { TPSA, } \\
\mathrm{nm}^{2}\end{array}$ & $\begin{array}{c}\mathrm{nON}(\mathrm{TPSA}), \\
\mathrm{nm}^{2}\end{array}$ & $\begin{array}{c}\text { nOHNH (TPSA) } \\
n^{2}\end{array}$ & $\mathrm{~V}, \mathrm{~nm}^{3}$ & \\
\hline Indole (Ind) & 117 & 2.16 & 0.158 & $1(0.079)$ & $1(0.079)$ & 0.113 & 0.30 \\
\hline Tryptophan (Trp) & 204 & -1.08 & 0.791 & $4(0.396)$ & $4(0.396)$ & 0.185 & 0.35 \\
\hline Arginine (Arg) & 174 & -3.76 & 1.277 & $6(0.588)$ & $7(0.688)$ & 0.164 & 0.34 \\
\hline Creatinine $(\mathrm{Kp})$ & 113 & -1.15 & 0.587 & $4(0.391)$ & $2(0.196)$ & 0.101 & 0.30 \\
\hline $\mathrm{B}_{12}$ & 1355 & -1.95 & 4.621 & $27(2.902)$ & $15(1.720)$ & 1.150 & 0.65 \\
\hline
\end{tabular}

Note. Data obtained with Molinspiration Cheminformatics method; milogP is the method for $\log \mathrm{P}$ (octanol-water partition coefficient) prediction developed at Molinspiration; TPSA is the topological polar surface area of a molecule, $\mathrm{nm}^{2}$; nON (TPSA) is the number of hydrogen bond acceptors, $\mathrm{nm}^{2}$; $\mathrm{nOHNH}$ (TPSA) is the number of hydrogen bond donors, $\mathrm{nm}^{2}$; $\mathrm{V}$ is the volume of the adsorbate molecule, $\mathrm{nm}^{3} ; \mathrm{R}$ is the radii corresponding to the volume of the investigated molecules, $\mathrm{nm}$.

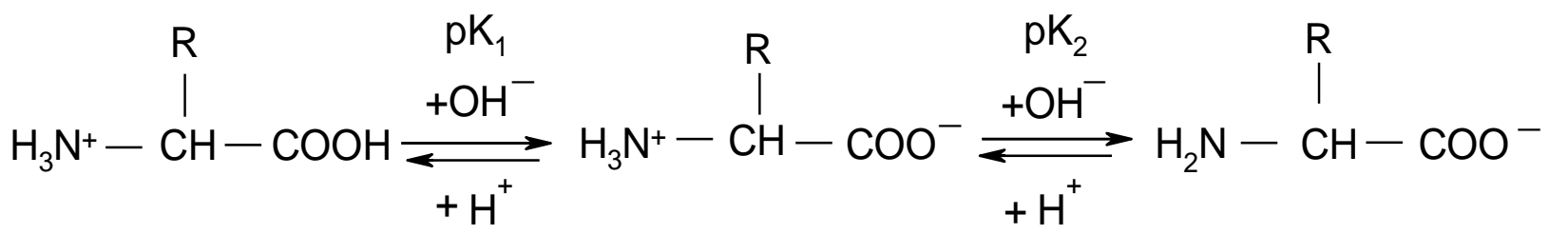<smiles>CN1CC(=O)N=C1N</smiles>

Scheme 2. Dissociation of amino acids and creatinine in a aqueous solutions.

dialysis and cause complications (including neuropathy) in patients undergoing ongoing extracorporeal blood purification.

The important characteristics of the employed adsorbates are presented in Table 2. It is seen that the adsorbated molecules volumes changes in the following order: $\mathrm{B}_{12}>\operatorname{Trp}>\mathrm{Arg}>\mathrm{Ind}>\mathrm{Kp}$; milogP decreased in the following order: Ind $>\operatorname{Trp}>\mathrm{Kp}>\mathrm{B}_{12}>$ Arg; TPSA, nON (TPSA) and nOHNH (TPSA) changes as follows: $\mathrm{B}_{12}>\operatorname{Arg}>\operatorname{Trp}>\mathrm{Kp}>$ Ind.

In aqueous solutions at $\mathrm{pH}<2$ amino acids exist in the form of cations, at neutral $\mathrm{pH}$ values - in the form of zwitterions, in an alkaline medium - in the form of anions [13]. Creatinine at low $\mathrm{pH}$ values exists in a protonated form, at $\mathrm{pH}=7$ - in a molecular form, in alkaline medium - in a deprotonated form $\left(\mathrm{pK}_{1}=4.83\right.$ and $\left.\mathrm{pK}_{2}=9.2\right)$ [14] (Scheme 2). The addition of acids to vitamin $\mathrm{B}_{12}$ leads to its transition to the protonated form; the addition of $0.1 \mathrm{M}$ alkali solutions at $100{ }^{\circ} \mathrm{C}$ for 10 minutes causes a loss of biological activity of vitamin $\mathrm{B}_{12}$, although its physical properties remain unchanged [15] (in Scheme 2 is not shown).

It is known that the adsorption maximum of amino acids occurs near their isoelectric points [16] (pI, 5.89 and 10.76 for tryptophan and arginine, respectively) [17]. It was found that at $\mathrm{pH}=4.5-10.3$ there is a slight decrease in the binding of vitamin $\mathrm{B}_{12}$ to human serum, and at very high acidity and alkalinity - a marked decrease in the binding of vitamin $\mathrm{B}_{12}$ [18].

The study of the sorption properties of KARBONTM carbon adsorbent restored by argon and hydrogen with respect to tryptophan and indole showed that the absorption capacity of both adsorbents is almost the same (Fig. 3,a). This is due to the high thermal stability of the surface functional groups of the activated carbon [19]. Therefore, it is not advisable to use higher temperatures and time to recover the samples.

Sorption capacity of tryptophan, arginine, indole, creatinine and vitamin $\mathrm{B}_{12}$ on oxidized KARBON ${ }^{\mathrm{TM}}$ as function of oxidation degree of the carbon sorbent surface was studied. It was proved that sorption capacity with respect to all investigated substances (Fig. 3,b) naturally decreases with increasing oxidation degree of carbon materials, which is explained by a smaller specific surface and the amount of mesopores of oxidized carbon (Table 1). Therefore, it is not advisable to apply the carbon surface modification with any oxidizing agent. 

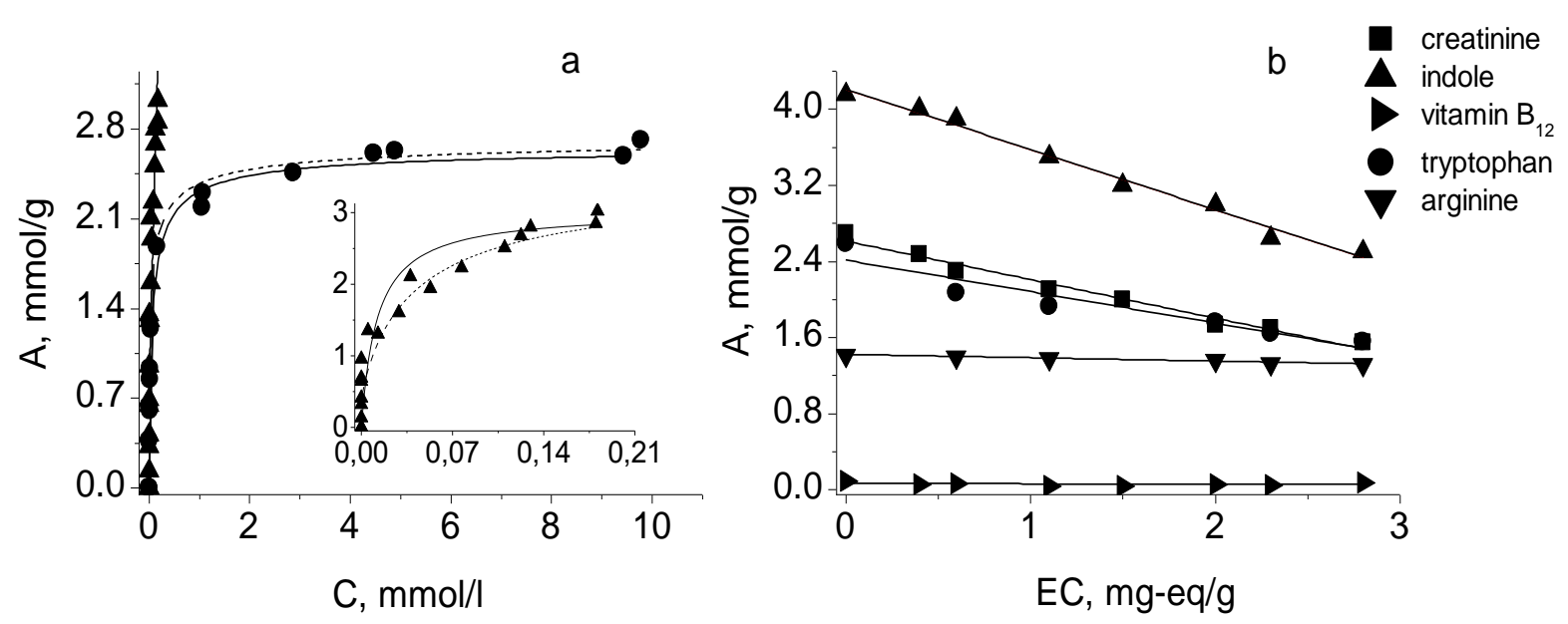

Fig. 3. Adsorption/desorption isotherms of tryptophan and indole on samples of KARBONTM- $0,35, \mathrm{H}_{2}-700{ }^{\circ} \mathrm{C} 1,5 \mathrm{~h}$ (---) and Карбон ${ }^{\mathrm{TM}}-0,35, \mathrm{Ar}-500{ }^{\circ} \mathrm{C} 1 \mathrm{~h} \mathrm{(--} \mathrm{-)} \mathrm{(a)} \mathrm{and} \mathrm{the} \mathrm{dependence} \mathrm{of} \mathrm{the} \mathrm{adsorption} \mathrm{capacity} \mathrm{of} \mathrm{substances} \mathrm{on}$ the degree of oxidation of Карбон ${ }^{\mathrm{TM}}-0,35, \mathrm{Ar}-500{ }^{\circ} \mathrm{C} 1 \mathrm{~h}(\sigma) ; \mathrm{pH} \approx \mathrm{pI}$.
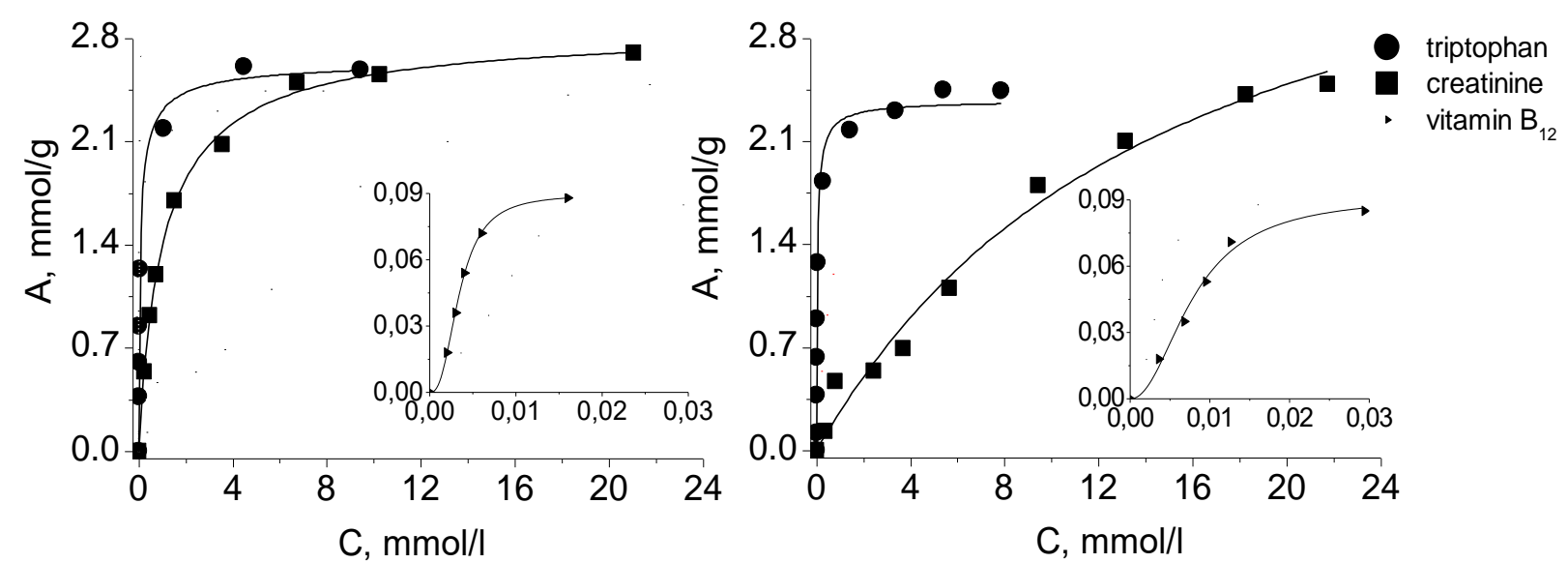

Fig. 4. Adsorption/desorption isotherms of tryptophan, creatinine and vitamine $\mathrm{B}_{12}$ on activated carbon KARBONTM $_{-} 0,35, \mathrm{Ar}-500{ }^{\circ} \mathrm{C} 1 \mathrm{~h}$ at $\mathrm{pH}=7,5$ (a) and $\mathrm{pH}=2,0$ (б).

The obtained results allowed to establish the SEC effect on the absorption capacity of amino acids, their metabolites and vitamins: Ind $>K p>\operatorname{Trp}>\operatorname{Arg}>B_{12}$. Comparing the influences of SEC and H-bond donors it is seen that their rows have an inverse relationship (Table 2). This indicates that vitamin $B_{12}$ has a large number of donor groups and a TPSA surface that forms hydrogen bonds. Therefore, the vitamin $\mathrm{B}_{12}$ adsorption is the least dependent on SEC. The adsorption of the indole, which contains the fewest donor groups and the TPSA surface, which does not form hydrogen bonds, is most dependent on SEC. The study of the sorption properties of KARBON $^{\mathrm{TM}}$ adsorbent treated with argon at $\mathrm{pH}=7.0$ 7.5 showed that its adsorption capacity is $2.6 ; 2.7$ and $0.09 \mathrm{mmol} / \mathrm{g}$ relative to tryptophan, creatinine and vitamin $\mathrm{B}_{12}$, respectively (Fig. $4, \mathrm{a}$ ). The high values of the adsorption capacity of the KARBON ${ }^{\mathrm{TM}}$ adsorbent with respect to amino acids and their metabolites are due to the fact that in the $\mathrm{KARBON}^{\mathrm{TM}}$ there are micropores with a radius of $0.6 \mathrm{~nm}$ [8]. Vitamin $B_{12}$ molecules have more branched structure than molecules of others adsorbates. Therefore, for the vitamin $\mathrm{B}_{12}$ adsorption it is not the adsorbent total pore volume that is important, but the presence in its structure of pores available to the molecules of the marker substance. It is known that vitamin $\mathrm{B}_{12}$ has dimensions of $1.14 \times 1.835 \times 1.412=2.954$ $\mathrm{nm}^{3}$; based on this, the radius of the vitamin $B_{12}$ molecule is $0.89 \mathrm{~nm}$. Therefore, pores with a radius of more than $0.9 \mathrm{~nm}$ are available for adsorption of $\mathrm{B}_{12}$ molecules. At the same time, for effective sorption, the sorbent must also have pores with a radius of 1.2 $1.6 \mathrm{~nm}$ [20] and 4 - $25 \mathrm{~nm}$ [21].

The adsorption capacity of tryptophan, creatinine and vitamin B12 is practically unchanged when the acidity of the medium changes from 7.5 to 2.0 (Fig. 4,b). It has been proven that vitamin $\mathrm{B}_{12}$ molecules do not contain groups that are capable of dissociation in the investigated $\mathrm{pH}$ range $(\mathrm{pH}=2-7$ ) [22]. We did not study the adsorption properties of argon-treated KARBON ${ }^{\mathrm{TM}}$ adsorbent with respect to indole, because this substance is not formed in the acidic environment of the human stomach [17]. 


\section{Conclusions}

The connection between structural-morphological, physicochemical and adsorption characteristics of the obtained KARBON ${ }^{\mathrm{TM}}$ carbon adsorbents is established. It is shown that the specific surface area, pore size distribution, hydrophobicity and adsorption activity of $\mathrm{KARBON}^{\mathrm{TM}}$ can be controlled by changing the type of modifier and heat treatment time.

The study of tryptophan, arginine, creatinine, indole and vitamin $\mathrm{B}_{12}$ adsorption on the $\mathrm{KARBON}^{\mathrm{TM}}$ carbon adsorbent with different hydrophobicity showed that the $\mathrm{KARBON}^{\mathrm{TM}}$ is a therapeutic and/or prophylactic agent for oral administration in chronic kidney and liver diseases.

Farbun I.A. - Candidate of Chemical Sciences, Senior Researcher of the Department of Fine and Inorganic Synthesis;

Trykhlib V.A. - Researcher of the Department of Fine and Inorganic Synthesis.

[1] R. Vanholder, R. De Smet, G. Glorieux, A. Argiles, U. Baurmeister, P. Brunet, W. Clark, G. Cohen, P.P. De Deyn, R. Deppisch, B. Descamps-Latscha, T. Henle, A. Jörres, H.D. Lemke, Z.A. Massy, J. Passlick-Deetjen, M. Rodriguez, B. Stegmayr, P. Stenvinkel, C. Tetta, C. Wanner, W. Zidek, Kidney International 63(5), 1934 (2003) (https://doi.org/10.1046/j.1523-1755.2003.00924.x).

[2] T. Niwa, Nagoya Journal of Medical Science 72(1-2), 1 (2010) (https://www.med.nagoyau.ac.jp/medlib/nagoya_j_med_sci/7212/p001-012_Niwa.pdf).

[3] D. Bergé-Lefranc, H. Pizzala, R. Denoyel, V. Hornebecq, J.-L. Bergé-Lefranc, R. Guieu, P. Brunet, H. Ghobarkar, O. Schäf, Microporous and Mesoporous Materials 119(1-3) $186 \quad$ (2009) (https://doi.org/10.1016/j.micromeso.2008.10.016).

[4] T. Mitome, Y. Uchida, Y. Egashira, K. Hayashi, A. Nishiura, N. Nishiyama, Colloids and Surfaces A: Physicochemical and Engineering Aspects 424(5), 89 (2013) (https://doi.org/10.1016/j.colsurfa.2013.02.022).

[5] C. Brunori, B.F. Viola, P. Maiorca, C. Cancarini, Blood Purification 26(1), 36 (2008) (https://doi.org/10.1159/000110561).

[6] Kh. Kurokava, K. Khibi, T. Kousaka, K. Sudzuki, Pat. 2627464C2 RU, ICP A 61 K 33/44, A 61 P 1/16, A 61 P 39/02, B 01 J 20/20, B 01 J 20/30, C 01 B 31/10. Publ. 20.11.2014, Bull. № 32;

[7] V.A. Trykhlib, V.V. Strelko, Pat. 109548 UA, ICP A 61 K 33/44, C 01 B 31/08, B 01 J 20/20, B 01 J 20/30. Publ. 25.08.2016, Bull. № 16/2016;

[8] F.I. Kazakov, V.V. Kirkovsky, The Medical Journal 1, 65 (2014).

[9] Y.V. Isaieva, I.A. Farbun, V.A. Trykhlib, Theretical and Experimental Chemistry 54(6), 414 (2019) (https://doi.org/10.1007/s11237-019-09589-3).

[10] I.A. Farbun, V.A. Trykhlib, N.N. Tsyba, Voprosy Khimii i Khimicheskoi Tekhnologii 129(2), 125 (2020).

[11] P. Ertl, B. Rohde, P. Selzer, Journal of Medical Chemistry 43, 3714 (2000) (https://doi.org/10.1021/jm000942e).

[12] K.S.W. Sing, D.H. Everett, R.A.W. Haul, L. Moscou, R.A. Pierotti, J. Rouquerol, T. Siemieniewska, Pure and Applied Chemistry 57(4), 603 (1985) (https://doi.org/10.1515/iupac.57.0007).

[13] Q. Gao, W. Xu, Y. Xu, D. Wu, Y. Sun, F. Deng, W. Shen, Journal of Physical Chemistry B 112(7), 2261 (2008) (https://doi.org/10.1021/jp0763580).

[14] B. Koubaissy, J. Toufaily, Z. Yaseen, T.J. Daou, S. Jradi, T. Hamieh, Adsorption Science and Technology 35(1-2), 3 (2017) (https://doi.org/10.1177\%2F0263617416666084).

[15] J. Kirschbaum, Analitical Profiles of Drug Substances 10, 183 (1981).

[16] J. Goscianska, A. Olejnik, R. Pietrzak, Adsorption 19(2-4), 581 (2013) (https://doi.org/10.1007/s10450-0139481-z).

[17] A.L. Lehninger, Principles of Biochemistry (Worth Publishers, Inc, 1982).

[18] P. Newmark, S. Mester, Biochimica et Biophysica Acta 343(3), 627 (1974) (https://doi.org/10.1016/03044165(74)90281-5).

[19] L. Li, X. Yao, H. Li, Z. Liu, W. Ma, X. Liang, Journal of Chemical Engineering of Japan 47(1), 21 (2014) (https://doi.org/10.1252/jcej.13we193).

[20] E.V. Veprikova, I.P. Ivanov, N.V. Chesnokov, B.N. Kuznetsov, Journal of Siberian Federal University. Chemistry 11(4), 488 (2018) (https://doi.org/10.17516/1998-2836-0093).

[21] J-B. Yang, L-C. Ling, L. Liu, F-Y. Kang, Z-H. Huang, H. Wu, Carbon 40(6), 911 (2002) (https://doi.org/10.1016/S0008-6223(01)00222-6).

[22] S.N. Lanin, S.A. Rychkova, A.E. Vinogradov, M.B. Viryasov, I.A. Vostrov, I.A. Shatalov, Sorbcionnye i Khromatograficheskie Processy 15(2), 179 (2015) (http://www.sorpchrom.vsu.ru/articles/20150204.pdf). 


\title{
І.А. Фарбун, В.А. Трихліб
}

\section{Вплив поруватої структури кокосових вуглецевих сорбентів та кислотності середовища на сорбцію деяких біологічно активних органічних сполук}

\author{
Інститут сорбиї та проблем ендоекологї НАН Украӥни, Київ, Україна, mandarin3169@ gmail.com
}

У статті вивчено регулювання гідрофобності вуглецевого адсорбенту Карбон ${ }^{\mathrm{TM}}$ шляхом відновлення його поверхні під час термічної обробки в аргоні та водні, а також окисненні нітратною кислотою. Досліджено адсорбційну здатність вугілля Карбон ${ }^{\mathrm{TM}}$ до триптофану, аргініну, індолу, креатиніну та вітаміну $\mathrm{B}_{12}$ як біологічно активних органічних сполук різної молекулярної маси. Встановлено, що сорбційна ємність зразків вугілля Карбон ${ }^{\mathrm{TM}}$ по відношенню до всіх вивчених сполук змінюється в ряду: Ind $>\mathrm{Cr}>\operatorname{Trp}>\mathrm{Arg}>\mathrm{B}_{12}$. Показано, що сорбційна ємність вугілля Карбон ${ }^{\mathrm{TM}}$, обробленого аргоном, при $\mathrm{pH}=7,5$ становить 2,$6 ; 2,7$ та 0,09 ммоль/г щодо триптофану, креатиніну та вітаміну В12 відповідно Адсорбційна здатність цих сполук майже не змінюється, коли $\mathrm{pH}$ середовища змінюється 3 7,5 до 2,0. Одержані результати дозволяють використовувати адсорбент Карбон ${ }^{\mathrm{TM}}$ як лікувальний та/або профілактичний засіб для перорального прийому при хронічних захворюваннях нирок та печінки, а також як гемосорбент для очищення крові поза організмом.

Ключові слова: адсорбція уремічних токсинів, адсорбція амінокислот, вуглецеві сорбенти, триптофан, аргінін, індол, креатинін, вітамін В12. 